\title{
An Association of the Arginase 1 Gene with Preschool Wheezing Phenotypes
}

\author{
Hartmut Grasemann ${ }^{1}$ and Fernando Holguin ${ }^{2}$ \\ ${ }^{1}$ The Hospital for Sick Children \\ ${ }^{2}$ University of Colorado Denver School of Medicine
}

January 8, 2021

\section{An Association of the Arginase 1 Gene with Preschool Wheezing Phenotypes}

Hartmut Grasemann and Fernando Holguin

Arginases are enzymes that metabolize L-arginine to form urea and L-ornithine. The two arginase isoforms, arginase I and arginase II, which are encoded by two different genes (ARG1 and ARG 2), are expressed in various cell types throughout the human body, including the lungs and airways. Arginase competes with nitric oxide synthase (NOS) for L-arginine as substrate, and increased arginase expression and activity in asthma reduces nitric oxide (NO) bioavailability, causing airways obstruction and contributing to reactive oxygen species production (1). Arginase also plays a role in allergen-induced airway remodeling in chronic asthma, presumably due to increased formation of L-ornithine, the precursor of L-proline and the polyamines (2). Proline is further metabolized to collagen and the polyamines putrescine, spermidine and spermine, which among other functions, also inhibit NOS. Increased production of endogenous NOS inhibitors including the polyamines as well as asymmetric dimethylarginine (ADMA), further contribute to the imbalance of NOS and arginases in asthma (figure 1).

Previous studies of genetic variations or single nucleotide polymorphisms (SNPs) in arginase genes had shown associations with atopy and asthma. For example, SNPs in both arginase genes were associated with atopy and asthma in children and with risk for asthma in adults $(3,4,5)$. Interestingly, ARG1 and ARG2 were also found to be associated with bronchodilator response in children and adults with asthma, and ARG1 with long term outcome on inhaled corticosteroid (ICS) therapy in adult asthma $(5,6,7,8,9)$.

Preschool wheeze is a common phenomenon, usually benign and mostly self-limited $(10,11)$. Different phenotypes of preschool wheeze have been described, including early transient wheeze, late onset wheeze and persistent wheeze (12). A more recent classifications distinguishes multiple trigger wheeze (MTW) from episodic wheeze $(\mathrm{EW})$, which is mainly caused by viral respiratory tract infections. The clinical usefulness of phenotype driven classifications has been questioned for a number of reasons including the longitudinal instability of phenotypes. However, some evidence suggests that MTW may be linked to later onset allergic asthma and MTW may therefore be more likely to respond to asthma treatment as compared to EW $(13,14,15,16,17,18)$. Interestingly, a more recent analysis of the natural history of MTW and EW in two large independent birth cohorts demonstrated that phenotypes may track over time (19), suggesting that the two indeed represent different disease entities and not just differences in severity of the same disease.

In a study by Gokmirza Ozdemir et al., published in this issue of the Journal, the authors report an association between arginase 1 gene polymorphisms and preschool wheezing phenotypes (20). In a cohort of 83 well characterized preschool wheezers with either multi trigger wheeze (MTW) or episodic wheeze (EW) phenotype of Turkish origin and matched controls, there was a difference in homozygous frequency of the ARG1 rs2781667T >C SNP between wheezing phenotypes and between patients with vs without allergic 
rhinitis. The homozygous frequency of this SNP in ARG1 was significantly higher in MTW vs EW, and in allergic rhinitis vs no allergic rhinitis. There were no associations of other tested SNPs in either ARG1 or ARG2 with preschool wheezing, allergic rhinitis, presence of aeroallergen sensitivity or tobacco exposure. Further analyses also showed significant differences in a number of haplotype frequencies in ARG1 between all wheezers and controls, and also between wheezing phenotypes. No associations were found with ARG2 in this study (20). Thus, these results show that in the population studied, variants in ARG1 but not ARG2 were associated with wheezing phenotypes in pre-school age.

This observation is exiting as the genotype-phenotype association implies that arginase I could be involved in the development of preschool wheeze and wheezing phenotypes, possibly through an effect on L-arginine availability for nitric oxide synthase (NOS) or by affecting airway remodelling. However, the population studied here was relatively small and the findings have not yet been confirmed by others. Therefore, the results need to be interpreted with caution and additional studies are needed for confirmation. Similarly, it is unclear at this point, whether the SNPs and haplotypes found to be different in frequency between groups, alter arginase expression or activity, and what the biological or molecular explanation could be for the observed associations. Nevertheless, these observations by Gokmirza Ozdemir et al. are promising, and once confirmed in larger and independent cohorts, also have the potential to help develop a genetic test for wheezing pre-schoolers that may predict future asthma risk and response to asthma therapies.

\section{References}

1) North ML, Grasemann H, Khanna N, Inman MD, Gauvreau GM, Scott JA. Increased ornithine-derived polyamines cause airway hyperresponsiveness in a mouse model of asthma. Am J Respir Cell Mol Biol. 2013 Jun;48(6):694-702.

2) Maarsingh H, Dekkers BG, Zuidhof AB, Bos IS, Menzen MH, Klein T, Flik G, Zaagsma J, Meurs H. Increased arginase activity contributes to airway remodelling in chronic allergic asthma. Eur Respir J. 2011 Aug;38(2):318-28.

3) Donthi S, Neela VSK, Gaddam S, Mohammed HH, Ansari SS, Valluri VL, Sivasai KSR. Association of increased risk of asthma with elevated arginase \& interleukin-13 levels in serum \& rs2781666 G/T genotype of arginase I. Indian J Med Res. 2018 Aug;148(2):159-168.

4) Li H, Romieu I, Sienra-Monge JJ, Ramirez-Aguilar M, Estela Del Rio-Navarro B, Kistner EO, Gjessing HK, Lara-Sanchez Idel C, Chiu GY, London SJ. Genetic polymorphisms in arginase I and II and childhood asthma and atopy. J Allergy Clin Immunol. 2006 Jan;117(1):119-26.

5) Vonk JM, Postma DS, Maarsingh H, Bruinenberg M, Koppelman GH, Meurs H. Arginase 1 and arginase 2 variations associate with asthma, asthma severity and beta2 agonist and steroid response. Pharmacogenet Genomics. 2010 Mar;20(3):179-86.

6) Duan QL, Gaume BR, Hawkins GA, Himes BE, Bleecker ER, Klanderman B, Irvin CG, Peters SP, Meyers DA, Hanrahan JP, Lima JJ, Litonjua AA, Tantisira KG, Liggett SB. Regulatory haplotypes in ARG1 are associated with altered bronchodilator response. Am J Respir Crit Care Med. 2011 Feb 15;183(4):449-54.

7) Litonjua AA, Lasky-Su J, Schneiter K, Tantisira KG, Lazarus R, Klanderman B, Lima JJ, Irvin CG, Peters SP, Hanrahan JP, Liggett SB, Hawkins GA, Meyers DA, Bleecker ER, Lange C, Weiss ST. ARG1 is a novel bronchodilator response gene: screening and replication in four asthma cohorts. Am J Respir Crit Care Med. 2008 Oct 1;178(7):688-94.

8) Sy HY, Ko FW, Chu HY, Chan IH, Wong GW, Hui DS, Leung TF. Asthma and bronchodilator responsiveness are associated with polymorphic markers of ARG1, CRHR2 and chromosome 17q21. Pharmacogenet Genomics. 2012 Jul;22(7):517-24.

9) Scaparrotta A, Franzago M, Marcovecchio ML, Di Pillo S, Chiarelli F, Mohn A, Stuppia L. Role of THRB, ARG1, and ADRB2 genetic variants on bronchodilators response in asthmatic children. J Aerosol Med Pulm Drug Deliv. 2019 Jun;32(3):164-173. 
10) Kurukulaaratchy RJ, Matthews S, Holgate ST, Arshad SH. Predicting persistent disease among children who wheeze during early life. Eur Respir J. 2003 Nov;22(5):767-71.

11) Caudri D, Wijga A, A Schipper CM, Hoekstra M, Postma DS, Koppelman GH, Brunekreef B, Smit HA, de Jongste JC. Predicting the long-term prognosis of children with symptoms suggestive of asthma at preschool age. J Allergy Clin Immunol. 2009 Nov;124(5):903-10.e1-7.

12) Martinez FD, Wright AL, Taussig LM, Holberg CJ, Halonen M, Morgan WJ. Asthma and wheezing in the first six years of life. The Group Health Medical Associates. N Engl J Med. 1995 Jan 19;332(3):133-8.

13) Schultz A, Devadason SG, Savenije OE, Sly PD, Le Souëf PN, Brand PL. The transient value of classifying preschool wheeze into episodic viral wheeze and multiple trigger wheeze. Acta Paediatr. 2010 Jan;99(1):56-60.

14) Sonnappa S, Bastardo CM, Wade A, Saglani S, McKenzie SA, Bush A, Aurora P. Symptom-pattern phenotype and pulmonary function in preschool wheezers. J Allergy Clin Immunol. 2010 Sep;126(3):51926.e1-7.

15) Brand PL, Baraldi E, Bisgaard H, Boner AL, Castro-Rodriguez JA, Custovic A, de Blic J, de Jongste JC, Eber E, Everard ML, Frey U, Gappa M, Garcia-Marcos L, Grigg J, Lenney W, Le Souëf P, McKenzie S, Merkus PJ, Midulla F, Paton JY, Piacentini G, Pohunek P, Rossi GA, Seddon P, Silverman M, Sly PD, Stick S, Valiulis A, van Aalderen WM, Wildhaber JH, Wennergren G, Wilson N, Zivkovic Z, Bush A. Definition, assessment and treatment of wheezing disorders in preschool children: an evidence-based approach. Eur Respir J. 2008 Oct;32(4):1096-110.

16) Brand PL, Caudri D, Eber E, Gaillard EA, Garcia-Marcos L, Hedlin G, Henderson J, Kuehni CE, Merkus PJ, Pedersen S, Valiulis A, Wennergren G, Bush A. Classification and pharmacological treatment of preschool wheezing: changes since 2008. Eur Respir J. 2014 Apr;43(4):1172-7.

17) Garcia-Marcos L, Martinez FD. Multitrigger versus episodic wheeze in toddlers: new phenotypes or severity markers? J Allergy Clin Immunol. 2010 Sep;126(3):489-90.

18) van Wonderen KE, Geskus RB, van Aalderen WM, Mohrs J, Bindels PJ, van der Mark LB, Ter Riet G.Stability and predictiveness of multiple trigger and episodic viral wheeze in preschoolers. Clin Exp Allergy. 2016 Jun;46(6):837-47.

19) Spycher BD, Cochrane C, Granell R, Sterne JAC, Silverman M, Pedersen E, Gaillard EA, Henderson J, Kuehni CE. Temporal stability of multitrigger and episodic viral wheeze in early childhood. Eur Respir J. 2017 Nov 2;50(5):1700014.

20) Gokmirza Ozdemir, P, Eker D, Celik V, Beken B, Gurkan H, Yazicioglu M, Sut N. The relationship between arginase genes polymorphisms and preschool wheezing phenotypes. Pediatr Pulmonol. 2020 ....

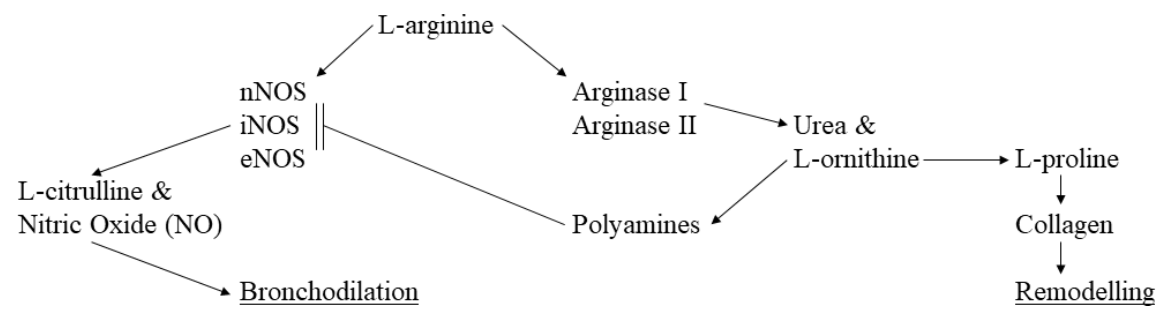

